\title{
Transformation of Wetland Local Wisdom Values on Activities of Swamp Buffalo Breeding in Social Science Learning Practice
}

\author{
Rochgiyanti \\ History Education Department \\ Faculty of Teacher Training and Education \\ Universitas Lambung Mangkurat \\ Banjarmasin, Indonesia
}

\author{
Heri Susanto \\ History Education Department \\ Faculty of Teacher Training and Education \\ Universitas Lambung Mangkurat \\ Banjarmasin, Indonesia
}

\begin{abstract}
Education is closely related to the instilment of values, such as the values of local wisdom in each community. Banjarese community as a society with cultural characteristics in the wetlands has a cultural richness characterized by wetland communities, including in various economic activities. This study examines the values of local wisdom formed in wetland communities in swamp buffalo breeding activities, and how these local wisdom values can be transformed in Social Science learning. The transformation is related to how to use the values of local wisdom in educational practice as a moral teaching, as well as a source of knowledge for cognitive reinforcement related to multiculturalism. The transformation of values is related to the development of Social Science teaching materials.
\end{abstract}

Keywords - transformation, local wisdom values, wetlands, Social Science learning

\section{INTRODUCTION}

Education philosophically can be defined as an effort to prepare citizens to own and reflect on a set of knowledge, values, and order of life needed in social life widely. The concept means that education cannot be separated from effort to enrich the pedagogic values that become moral teachings in educational practice. Thus, the education practice is also concerned with how to absorb as much as possible the values of local wisdom as the value and philosophical basis of the implementation of education. In the geographical context of Banjar characterized by wetlands, the local wisdom values are characterized by the local wisdom of the typical wetland community. The distinctiveness should be developed into educational values.

Local wisdom is understood differently, depending on the point of view used by experts. [1], for example, emphasizes that the advantages of local wisdom are derived from the results of continuous and local trials. The advantage lies in the flexible and resistant nature in adapting to environmental changes, so the advantage can be sustainable in the utilization of natural resources and the environment. In addition, local knowledge is also more directed to the adjustment of ecological systems so as to maintain the sustainability of the ecological system. From this opinion, it can be concluded that local wisdom is as an experience, not just a process of the past, so it has a goal to deal with the faced problems.

The transformation of the values of local wisdom, in this case the community of wetlands in the swamp buffalo breeding activities, is important to do. The transformation is related to how to use the values of local wisdom in educational practice as a moral teaching, as well as a source of knowledge for cognitive reinforcement related to multiculturalism. Based on the background, the aims of the study are as follows:

1. To identify local wisdom values of the wetland community in swamp buffalo breeding activities in Tabatan Baru Village;

2. To describe the transformation of the local wisdom values by the wetland community in the swamp buffalo breeding activity in Tabatan Baru Village for Social Science learning practice.

\section{METHOD}

The location of this study was Kuripan sub-district in two villages, namely Jambu Baru Village and Tabatan Baru Village, Kuripan Sub-district, Barito Kuala District. This study used qualitative method. Observations were used to extract data about the physical location in swamp land, the activities of the residents, and the used equipment. In addition to observation, the researchers conducted interviews to extract data from informants about their knowledge of wetlands, climate change and their business plans. The researchers also listened to the community's conversations by finding conversational moments in the local language heard anytime, anywhere, and from anyone since this conversation stores information in the form of local terms which involve local wisdom [2].

The researchers also conducted visual documentation in the form of photographs to dig up data about farmers, farm sites, and farm equipment. In addition, the researchers collected written archives to explore research supporting data. In addition, interviews were conducted with community leaders and other villagers to answer research questions. The analysis of the research findings was conducted with 
descriptive analysis model referring to the objectives of the study

\section{RESULT AND DISCUSSION}

A. Local Wisdom Values of Wetland Community in Swamp Buffalo Breeding Activities in Tabatan Baru Village

Local wisdom can be defined as a local cultural treasure that contains a living policy; the way of life that accommodates wisdom. In Indonesia -which we know as Nusantara- local wisdom is not only applied locally to a particular culture or ethnic, but it can be said to be crosscultural or cross-ethnic to form a national cultural value. For example, almost every local culture in the archipelago is known for local wisdom that teaches mutual cooperation, tolerance, work ethic, and so on. In general, ethics and moral values contained in local wisdom are taught hereditary, passed down from generation to generation through oral literature (among others in the form of proverbs and proverbs, folklore), and manuscripts [3].

If the point of view expressed by Ahimsa-Putra [2] is used, local wisdom is identified as a value built through the life experiences of a society and values passed down through generations within a society. Furthermore, these values are built through patterns of interaction and action. In relation to non-agricultural business especially in swamp buffalo breeding conducted by the community in Tabatan Baru Village, the local wisdom formed and inherited by the community are as follows:

\section{1) Adaptation of wetland ecology}

The soil that generally forms the wetlands of South Kalimantan is the alluvial soil and peat. Tidal swamps and irrigated rice fields generally have alluvial soil, while swamps of lebak and shallow lakes have alluvial soils and some of peat soil. Peatlands as swamp areas with tidal water impact drought during the dry season and flood in the rainy season. The ability to build the economic structure of the community in Tabatan Baru Village is based on the ability to adapt to the ecological conditions of the wetlands. The tidal conditions are exploited by these villagers by selecting an economic field that allows them to survive under natural conditions that can drastically change. Breeding and raising pattern of swamp buffalo in Kalimantan generally and in Tabatan Baru Village especially consider tidal swamp conditions. The form of ecological adaptation of wetlands materially in the breeding and raising of Rawa Buffalo can be seen, among others, from the manufacture of pulleys that use the material in accordance with swamp area. The use of highly resistant timber and ulin woods suggests that people in swamp area have adaptive behavior in developing construction technology. In general, Banjarese people are very familiar with the use of building materials because the materials have been tested very well with the condition of swamp area. Furthermore, the raising cycle of swamp buffalo used by the people in Tabatan Baru Village also shows the strong adaptation of ecological adaptation by the breeders. In the raising cycle, the farmers use an intensive raising phase in the early age of buffalo and then an extensive raising phase where swamp buffalos are released and they feed independently.

2) Indigenous science and technology

'Indigenous' is defined as a scientific study of native (original) human behavior or mind, which is not transported from other territory, and is designed for the community [4]. In the context of the maintenance of swamp buffalo in Tabatan Baru Village, the knowledge and technology used in swamp buffalo caretaking indicates that the community has original knowledge developed and passed on among swamp buffalo breeders. Such knowledge, among other things, is the creation of the possession of buffalo in the ear. The naming of the ear feature refers to local terms that are agrarian and maritime, such as Tali Layar, Lirih, Sapit Hundang and Tajam Hampang. Sapit as a word from Banjarese language means claw, while Hundang means Shrimp, so Sapit Hundang means Claw of Shrimp. Hampang in Banjarese language based on the researcher's study has several meanings. The first meaning is the fish cultivation system by fencing a water area to keep the fish (commonly used in the term 'mehampang iwak'); Second, it is an easy tool used in keeping fish and is usually made of bamboo. Moreover, the word 'Lirih' in Banjar means separating the fiber.

\section{3) In-group economy solidarity}

The kakarun system used among swamp buffalo breeders shows that the economic solidarity among buffalo breeders and buffalo caretakers is very strong. Economic relations based on mutual trust without a written agreement show that among them has built up a very strong economic solidarity. The second fact that demonstrates the strength of economic solidarity is, when livestock die from disease or because of other reasons, the owner/breeder of Buffalo never suspects or raises the problem between the breeder and the Buffalo caretaker. The kakarun system also allows the buffalo breeders or caretakers to build ownership of economic resources, in this case swamp buffalo. With this system, the caretakers are entitled to own the part of the buffalo they keep, so the caretakers who initially do not have the buffaloes will have their own buffalo. This pattern is a common pattern used in many communities in Indonesia and is one of the most visible features of economic solidarity in rural Indonesian society.

B. The Transformation of Local Wisdom Values by Wetland
Community in Swamp Buffalo Breeding Activities in Tabatan Baru Village for Social Science Learning Practice

Article 37 of Law No. 20 of 2003 affirms that the curriculum of basic and intermediate education shall contain Social Sciences (IPS), which in its description mentions that the learning materials of Social Sciences, which among others are earth sciences, history, economy, health, are intended to develop the knowledge, understanding, and analysis ability of learners on the social conditions of their community.

According to National Council for Social Studies (NCSS) (1992) in Maryani [5], Social Studies (Social Science) is defined as follows: 
"Social studies are the integrated study of the social sciences and humanities to promote civic competence. Within the school program, social studies provides coordinated, systematic study drawing upon such disciplines as anthropology, archaeology, economics, geography, history, law, philosophy, political science, psychology, religion, and sociology, as well as appropriate content from the humanities, mathematics, and the natural sciences. The primary purpose of social studies is to help young people develop the ability to make informed and reasoned decisions for the public good as citizens of a culturally diverse, democratic society in an interdependent world "

Social Science subject aims to enable learners to have the following skills:

1. Understanding the concepts related to the life of society and its environment

2. Having logical and critical thinking, curiosity, problem solving, and skills in social life

3. Having commitment toward social values and humanity

4. Communicating, cooperating and competing in a pluralistic society at the local, national, and global levels [6].

In relation to local wisdom values in swamp buffalo breeding activities, some relevant concepts in Social Science learning that can be combined with local wisdom values of wetland communities in swamp buffalo breeding activities are as follows. The first one is human. The study of social studies is a variety of human activities. In relation to local wisdom values of wetland communities in swamp buffalo breeding activities, buffalo breeders exhibit adaptation behavior towards nature, innovation in livestock activities, and show strong solidarity among the community. The concept of human beings in relation to local wisdom is the source of ideas that produce culture. In this context, it is seen that the view used by the swamp buffalo breeders is not an anthropocentrism view that puts people at the center of ecological cycles, but places nature as the center and source of ideas that produce local wisdom in the wetland environment.

Man as a member of society with the environment of residence is an integral life entity. The human environment basically consists of: (1) the bio-physical environment, (2) the social environment, and (3) the cultural environment [7]. The biophysical environment is natural, and its survival is determined by water. Social environment or community is determined by the continuity of the order of interaction (relationship). The cultural environment is the result of thought, knowledge, technology, law, and so forth, which is determined by its continuing existence of its supporters' creativity.

The second concept is environment. In its popular use, the word 'environment' is generally equated with characteristics or prominent features that characterize natural habitats: weather, flora and fauna, soils, rain patterns, and even the presence of underground minerals [8]. In connection with the notion, the existence of underground minerals such as coal is also one element of the environment.
Environment in the view of cultural ecology is an environment that has undergone cultural modification. The formula implies an inevitable element of circulation: environment $\rightarrow$ culture, or culture $\rightarrow$ environment [8]. Thus, one of the basic rules of cultural ecology is the distinction between the environment as it is and the effective environment. The effective environment is the environment as it is conceptualized, exploited and modified by humans [8]. In connection with the wetland environment, we can identify the ability to raise and breed buffalo in the community of Tabatan Baru Village inherited from generation to generation and has lasted from 4 or 5 generations. Almost all the caretakers are male since watching the swamp buffaloes requires strength and skills that are usually only controlled by men. The large number of buffaloes that can be cultivated can reach 400 buffalos from many breeders and the extent of swamp area to be monitored is the reason why this work tends to be more suitable for men. These facts show that environmental factors greatly affect how the culture is formed.

The third concept includes social and cultural systems. Humans live together in a group called society, and living together produces a culture. There are many definitions of culture. Etymologically, culture can be interpreted as all efforts and human actions to cultivate land and change nature [9]; whereas according to the science of anthropology, culture is the whole system of ideas, actions, and the work of human beings in the life of society which is made as the possession of human by learning [9]. Culture according to Linton is defined as the way of life, which includes way of thinking, way of feeling, and way of doing [10].

Because of its location along the coastal river, the daily life of this village is strongly influenced by the existence of the river. For example, to meet the daily needs such as the needs of public toilets, many community members use the river. To fulfill the need of clean water, some community members treat the river water by depositing it to separate the clean water with mud streams, so the water becomes cleaner and clearer. This evolving culture shows the cultural features of Banjarese communities living on the coastal rivers. The river in the daily life of the people in Tabatan Baru Village is the vein of the economy and the source of livelihood. This can be seen, for example, how they are so dependent on the river both for reaching the district capital as well as for daily needs.

The fourth concept is welfare. When viewed from the economic potential, actually swamp buffalos are still very promising. In addition, the breeding and raising of swamp buffaloes are also quite economical since breeders do not need to find grass like breeding cattle. They can take advantage of existing pasture land, so one way to maintain continuity of swamp buffalo breeding and its optimization is to maintain the availability of swamp buffalo pastures. It also requires more roles from the Animal Husbandry Department to provide guidance and assistance for swamp buffalo health maintenance.

One of the huge economic potentials which becomes swamp buffalo marketing opportunity is on the eve of Idul Adha. Demand of cattle and buffalo in this occasion is high. 
Both prices of cattle and buffalo tend to rise very significantly ahead of the holiday, so this condition can be a very profitable marketing opportunity. Usually the meat needs are still in supply from other areas, such as from Amuntai and several other areas. The high selling price ahead of Idul Fitri Day becomes great potential for swamp buffalo breeders to improve their welfare.

The fifth concept is economic behavior. In addition to agricultural business, there are still non-agricultural efforts undertaken by people who live in tidal land, such as research conducted by Budhi and Nasrullah who found that generally people who live on the banks of the Barito River in Barito Kuala District pursue business by searching for fish, taking rattan, and pursuing small industries [11].

South Kalimantan is famous for duck and swamp buffalo farms (hadangan). Swamp buffalo is unique because it lives in the waters (swamp) which makes the so called swamp buffalo. The swamp buffaloes at the research sites are traditionally maintained, shepherded in swamp areas during the day and inserted into kennels called kalang. Buffalo maintenance system in Tabatan Baru Village, Kuripan District, Barito Kuala Regency is very unique. They use the system with the local term "mangangarun kerbau". Mangangarun is a livestock-raising system between buffalo breeders and buffalo caretakers.

The last concept is change. The biggest challenge faced by the farmers today is the change of land use due to expansion of oil palm plantation area. The swamp buffers cultivated by these farmers require a large land area. Existing land is used as a pasture where buffalo look for feed and activities. The change of land use is very influential to forage that can be consumed by buffalo, so it might cause problems, such as lack of food, low body resistance, disease and even death. Palm processing waste that flows with swampy waters in grazing areas unknowingly contains harmful pollutants for the survival of swamp buffalo.

Based on the results of the field study, limited and reduced grazing areas due to shifting land use to palm oil plantations is one of the important grievances for today's farmers. The dividing wall between the grazing area and the oil palm plantation area is clearly visible, and the high dumped soil becomes a very contrasting long line.

If the values of local wisdom are transformed in educational practice, in this case Social Science learning is increasingly enriching IPS learning resources. The transformation model of local wisdom values that can be developed in the teaching practice is shown in Figure 1

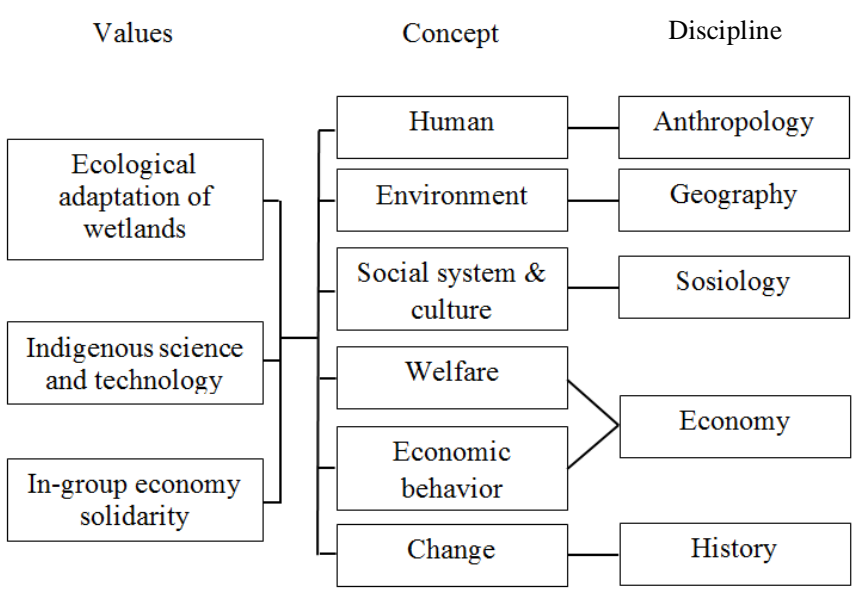

Fig 1. Transformation Model of Local Wisdom Values in Social Science Learning.

Figure 1 shows the linkage among local wisdom values of wetland communities in swamp buffalo breeding activities for Social Science learning practice. Thus, the transformation of values is related to the development of Social Science teaching materials.

\section{CONCLUSION}

Ethics and moral values contained in local wisdom are taught inheritedly, passed down from generation to generation through oral literature (in the form of proverbs and proverbs, folklore), and manuscripts. In relation to non-agricultural business, especially in swamp buffalo breeding business conducted by people of Tabatan Baru Village, local wisdom is established and inherited by the community and among others are ecological adaptation of wetlands, indigenous science and technology, and in-group economy solidarity. In addition, the concepts of Social Science learning is related to human, environment, social and cultural system, prosperity/welfare, economic behavior, and change. The transformation of these values leads to the development of Social Science teaching materials

\section{REFEFENCES}

[1] Wahyu, "Penguatan Kearifan Sungai: Kasus Banjarmasin", Makalah pada seminar sehari tentang Sumbangan Ilmu-ilmu Sosial (Sosiologi dan Antropologi) dalam Penguatan Kearifan Lokal (Budaya Sungai, 1 Oktober 2005, Kampus Unlam Banjarmasin, 2005.

[2] H.S. Ahimsa-Putra, "Ilmuwan Budaya dan Revitalisasi Kearifan Lokal Tantangan Teoritis dan Metodologis", Makalah disampaikan pada Rapat Senat Terbuka Dies Natalis ke-62 Fakultas Ilmu Budaya Universitas Gadjah Mada, Yogyakarta, 2008

[3] S. Suyatno, Revitalisasi Kearifan Lokal Sebagai Upaya Penguatan Identitas Ke-Indonesiaan, retrieved from http://badanbahasa.kemdikbud.go.id/lamanbahasa/artikel/1366, 3 Mei 2015), 2015.

[4] U. Kim, Y. Kuo-Shu and H. Kwang-Kwo, Indigenous and Cultural Psychology, Memahami Orang dalam Konteksnya, Yogyakarta: Pustaka Pelajar, 2010

[5] E. Maryani, Pengembangan Program Pembelajaran IPS untuk Peningkatan Keterampilan Sosial, Bandung: CV. Alfabeta, 2011.

[6] BSNP, Permendiknas RI No. 22 Tahun 2006 tentang Standar Isi untuk Satuan Pendidikan Dasar dan Menengah, Jakarta, 2006.

[7] Yosin, Beberapa Konsep Dasar: Ekologi, Sosial, Budaya, Dalam http://yosin.wordpress.com, retrieved from 25 Desember 2010 
[8] D. Kaplan, and Robert A. Manners, Teori Budaya, Yogyakarta: Pustaka Pelajar, 2002

[9] Koentjaraningrat, Pengantar Ilmu Antropologi, Jakarta: Rineka Cipta, 2009.
[10] Rahardjo, Pengantar Sosiologi Pedesaan dan Pertanian, Yogyakarta: Gadjah Mada University Press, 1999.

[11] S. Budhi, Nasrullah, DAS Barito: Kajian Sosial Ekonomi Program Berbasis Community Development, CRDS Kalsel dan PT Adaro, 2004 